\title{
The importance of museum collections in determining biodiversity patterns, using a freshwater mussel Unio caffer (Krauss 1848) as an example
}

\begin{tabular}{|c|c|}
\hline \multicolumn{2}{|c|}{$\begin{array}{l}\text { Authors: } \\
\text { Bayanda Sonamzi }^{1} \text { (D) } \\
\text { Musa C. Mlambo }^{1} \text { (D) } \\
\text { Chris C. Appleton }{ }^{2} \text { (1) } \\
\text { Helen M. Barber-James }^{1,3}\end{array}$} \\
\hline \multicolumn{2}{|c|}{$\begin{array}{l}\text { Affiliations: } \\
{ }^{1} \text { Department of Freshwater } \\
\text { Invertebrates, Albany } \\
\text { Museum, Affiliated Research } \\
\text { Institute of Rhodes } \\
\text { University, Grahamstown, } \\
\text { South Africa }\end{array}$} \\
\hline \multicolumn{2}{|c|}{$\begin{array}{l}{ }^{2} \text { School of Life Sciences, } \\
\text { University of KwaZulu-Natal, } \\
\text { Durban, South Africa }\end{array}$} \\
\hline \multicolumn{2}{|c|}{$\begin{array}{l}{ }^{3} \text { Department of Zoology } \\
\text { and Entomology, Rhodes } \\
\text { University, Grahamstown, } \\
\text { South Africa }\end{array}$} \\
\hline \multicolumn{2}{|c|}{$\begin{array}{l}\text { Corresponding author: } \\
\text { Musa Mlambo, } \\
\text { musa.mlambo@gmail.com }\end{array}$} \\
\hline \multicolumn{2}{|c|}{$\begin{array}{l}\text { Received: } 23 \text { July } 2018 \\
\text { Accepted: } 18 \text { Jan. } 2019 \\
\text { Published: } 24 \text { June } 2019\end{array}$} \\
\hline \multicolumn{2}{|c|}{$\begin{array}{l}\text { How to cite this article: } \\
\text { Sonamzi, B., Mlambo, M.C., } \\
\text { Appleton, C.C., Barber-James, } \\
\text { H.M., 2019, 'The importance } \\
\text { of museum collections in } \\
\text { determining biodiversity } \\
\text { patterns, using a freshwater } \\
\text { mussel Unio caffer (Krauss } \\
\text { 1848) as an example', } \\
\text { Bothalia } 49(1) \text {, a2400. } \\
\text { https://doi.org/10.4102/abc. } \\
\text { v49i1.2400 }\end{array}$} \\
\hline \multicolumn{2}{|c|}{$\begin{array}{l}\text { Copyright: } \\
\text { C 2019. The Authors. } \\
\text { Licensee: AOSIS. This work } \\
\text { is licensed under the } \\
\text { Creative Commons } \\
\text { Attribution License. }\end{array}$} \\
\hline \multicolumn{2}{|l|}{ Read online: } \\
\hline 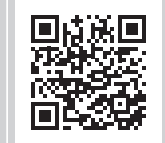 & $\begin{array}{l}\text { Scan this QR } \\
\text { code with your } \\
\text { smart phone or } \\
\text { mobile device } \\
\text { to read online. }\end{array}$ \\
\hline
\end{tabular}

Background: Two recent distributional maps of the African freshwater mussel Unio caffer (Krauss 1848) in South Africa represented an incomplete picture compared to the records held by the national museums.

Objectives: This study is partly in response to them, with the aim to compare and contrast the distribution maps of the published papers with the distribution records held by the national museums.

Method: We requested the distribution records of $U$. caffer from four South African museums. We visited and worked on the $U$. caffer collections of three of these museums to confirm the taxonomic identity of their specimens and gather occurrence records. We also extracted the distributional records from the two published maps, and plotted all these records using the geographic information system, ESRI ArcGIS.

Results: The distribution map based on the museum records showed that this species occurred in all nine provinces of the country, thus revealing a much broader historical occurrence than previous known.

Conclusion: This study demonstrates the crucial function of museums, natural history collections in facilitating understanding about biodiversity patterns using $U$. caffer distribution as an example. However, as museum records mainly show historical occurrence, there is a need to conduct further studies to assess the current population trends of this species. Although the current International Union for Conservation of Nature (IUCN) conservation assessment of this species is Least Concern, pressures on native fish, which host the larval stages of this mussel, and the declining environmental conditions of rivers in the country may affect the conservation status in the near future.

Keywords: museum collections; Unionoida; disjunct distribution; freshwater Bivalvia; South Africa.

\section{Introduction}

Freshwater mussels are the most diverse of all freshwater bivalves (Bauer \& Wachtler 2001; Bogan 2008; Graf \& Cummings 2007), and yet their conservation status is precarious (Bogan 1993; Lydeard et al. 2004; Régnier, Fontane \& Bouchet 2009; Strayer et al. 2004). This is unfortunate given the crucial structural and functional roles that they have been shown to play in the ecosystem (Vaughn \& Hakenkamp 2001). Together with deteriorating water quality (e.g. Watters 1999), extrinsic factors that plague freshwater resources in general (i.e. habitat deterioration, flow alterations and overexploitation) are also responsible for freshwater mussels decline. Intrinsically, freshwater mussels have several life history traits that make them particularly vulnerable (Bauer \& Wachtler 2001; Strayer 2008). For example, the larval stage is an obligatory parasite on fish meaning that without the host fish they are unable to complete their life cycles. Consequently, their occurrence in a locality is wholly dependent on the distribution of the host fish (Jubb 1976; Schwalb et al. 2012).

Unio caffer (Krauss 1848) is a freshwater mussel endemic to the southern African region (Appleton 2002; Brown 1967, 1978; Mandahl-Barth 1988). The other congenerics occur in the Palaearctic region, including North Africa (Froufe et al. 2016; Khalloufi et al. 2011). Its phylogeographic relationship with the Palaearctic congenerics has not been fully determined (Graf \& Cummings 2007). Based on its disjunct distribution, this taxon has long been treated as a separate genus on its own as Cafferia caffer (Mandahl-Barth 1988). However, based on adult shell morphology and 
detailed soft part anatomy, Heard and Vail (1976) synonymised Cafferia caffer with $U$. caffer, thus eliminating the genus Cafferia Simpson, 1900. The disjunct distribution of organisms between the Palaearctic, especially southern Europe and southern Africa, is widely reported for many taxa, both flora and fauna. Examples of other freshwater organisms displaying this disjunct distribution include certain mayflies; for example, the European Prosopistoma pennigerum (Müller 1785) (Prosopistomatidae) is genetically close to Prosopistoma crassi (Gillies 1954), which occurs in South Africa (Barber-James 2010). The diving beetle, Capelatus prykei Turner \& Bilton, 2015, endemic to the Western Cape of South Africa, has its nearest relative in the Palaearctic (Bilton et al. 2015). Several other taxa also support this distribution pattern (see Bologna et al. 2008). This phenomenon probably represents vicariant relicts of an ancient continuous biome extending throughout Africa until the late Neogene (Pliocene).

Inadequate knowledge of taxonomy and distribution patterns of a species may lead to ineffective conservation strategies (Prié, Puillandre \& Bouchet 2012). Two recent papers published on the distribution of $U$. caffer in South Africa are both inaccurate. De Kock and Wolmarans (2010) used locality records from the National Freshwater Snail Collection (NFSC) housed at North-West University, reporting that $U$. caffer does not occur in the Western Cape. This was incorrect, as Connolly (1939) recorded it from Retreat and Princess vleis in the Cape Peninsula, and Appleton (2002) alluded to its apparent disappearance from the south-western Cape in the intervening years. Graf and Cummings (2011) used museum records from Europe, North America and Australia to assess the richness and endemism of African freshwater mussels. Unfortunately, no museum records from African museums were consulted for this article, which led to incomplete conclusions about their distribution, implying that $U$. caffer does not occur in five of the nine provinces of South Africa. Consequently, this study was conducted to provide comprehensive, updated distributional occurrence maps of $U$. caffer based on South African museums records.

Ultimately, this article aims to produce an integrated distribution map of $U$. caffer in South Africa, combining all the available records including those of De Kock and Wolmarans (2010) and Graf and Cummings (2011), complementing them with those from four local South African museums, together with the personal collections of the third author. This allows for comparisons between the published maps (De Kock \& Wolmarans 2010; Graf \& Cummings 2011) and with this study. Production of an up-to-date distribution map will assist conservation managers and the broader society to make informed decisions about this species, which has experienced significant contraction in its historical distribution. Given its complex life history, which involves a host fish to complete its life cycle, and requirement for good water quality, this species is a good indicator species to reflect ecological conditions of aquatic ecosystems.

\section{Materials and methods}

Occurrence records were sourced from four South African museums known to have large collections of mollusca, namely Albany Museum in Grahamstown (AMGS), Iziko South African Museum in Cape Town (SAMC), KwaZuluNatal (KZNM) in Pietermaritzburg and East London Museum in East London (ELM). Albany Museum in Grahamstown had the highest number of samples (Figure 1), followed by ELM, KZNM and SAMC (Table 1). Within each sample, the number of individual specimens with both shells still joined together varied considerably, from one to a maximum of 15 , but as shells easily come apart when dry, it was considered unnecessary to reconstruct these to count them. These records were complemented with seven additional records privately held by the third author of this study (Table 1). Taxonomic identifications using Appleton (2002) were based on shell morphology as most specimens had no fleshy internal tissue left, as many were collected already dried out. According to one of the collector's notes (Carl J. Vernon, who collected a substantial portion of the material held in AMGS and ELM collections), 'most of the mussels were collected during times of drought'. Similarly, Appleton and la Hausse de Lalouvière (1987) reported that most of the mussels in their study were pulled out of drying river beds.

The U. caffer collections of three institutions, AMGS, KZNM and ELM, were intensively studied, with each specimen inspected and its taxonomic identity confirmed. A few

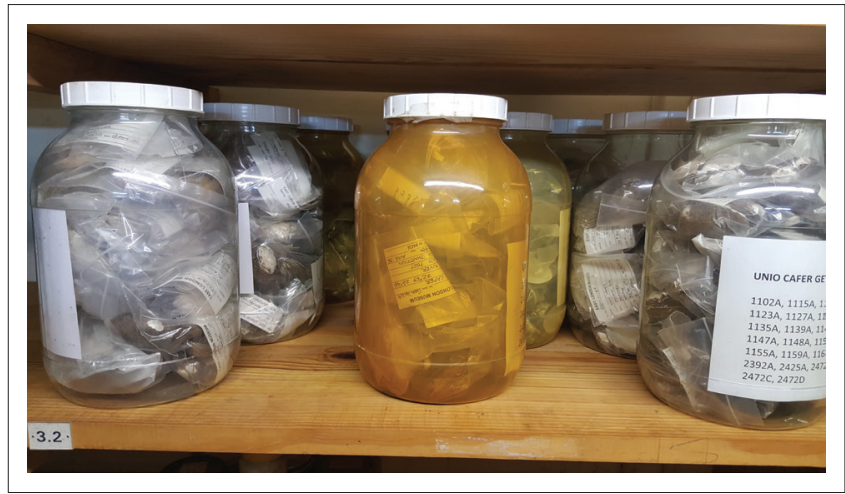

Source: Photo courtesy of Musa C. Mlambo

FIGURE 1: Examples of empty shells of Unio caffer in the collection at Albany Museum.

TABLE 1: Numbers of records in the reviewed collections and the years in which they were accessed.

\begin{tabular}{lcccc}
\hline Variables & $\begin{array}{c}\text { Number } \\
\text { of } \\
\text { records }\end{array}$ & $\begin{array}{c}\text { Years covered } \\
\text { (oldest- } \\
\text { youngest) }\end{array}$ & $\begin{array}{c}\text { Number of } \\
\text { records from } \\
\text { 1980 to 1999 }\end{array}$ & $\begin{array}{c}\text { Number of } \\
\text { records from } \\
\text { 2000 to 2017 }\end{array}$ \\
\hline $\begin{array}{l}\text { De Kock and Wolmarans } \\
\text { (2010) }\end{array}$ & 55 & $1958-2014$ & $7 \dagger$ & 3 \\
Graf and Cummings (2011) & 5 & $1913-1989$ & 4 & 0 \\
$\begin{array}{l}\text { Current study } \\
\quad \text { Albany Museum }\end{array}$ & 252 & $1911-2011$ & 229 & 8 \\
$\quad$ East London Museum & 147 & $1918-2011$ & 129 & 11 \\
KwaZulu-Natal Museum & $57 \dagger$ & $1903-2008$ & 21 & 2 \\
Iziko Museum & 28 & $1896-1975$ & 21 & 0 \\
Appleton's collection & 7 & $1980-1987$ & 7 & 0 \\
\hline
\end{tabular}

$\dagger$, Majority of these specimens lacked a collection date. 
records from SAMC were trusted as being accurate. A large number of samples of $U$. caffer at AMGS and KZNM were not catalogued or digitised into an electronic database, and this study contributed to the updating of those collections.

For all records, geographic coordinates of the sites where the specimens were collected were noted. Where none was originally recorded, geo-referencing was performed using locality names and/or collector's notes, if present. In line with geo-referencing standards and taking into consideration that we are dealing with an aquatic species, the geographic coordinates of a given location in the specimen label were estimated to the nearest water body from the midpoint of that location. This was the case for most of the old specimens, which had labels like 'Pretoria district' and 'Zululand'. Similarly, there were cases where the locality name was the name of a river, some of them more than $200 \mathrm{~km}$ in length. In such cases, only the midpoint coordinates of the river were recorded. The inherently low accuracy of such a georeferencing process was not deemed to be a major issue for the general purpose of this study, as it deals with an historical collection, and is not necessarily dependent on fine-scale accuracy to be instructive. Similar geo-referencing techniques were used by De Kock and Wolmarans (2010) and Graf and Cummings (2011). The locality data provided in the supplementary material of Graf and Cummings (2011) and De Kock and Wolmarans (2010), both of whom kindly provided their data to the authors, were used to replot the maps based on these records. All the geographic coordinates were then plotted in ESRI Arc GIS (version 10.1).

\section{Ethical considerations}

This article followed all ethical standards for a research without direct contact with human or animal subjects.

\section{Results}

The records provided by De Kock and Wolmarans (2010) focus more on the north-eastern provinces of the country (Gauteng, Mpumalanga, Limpopo and North West provinces), with two localities in the central part of the Eastern Cape, as well as scattered localities along its northern border (Figure 2). However, they omit records of $U$. caffer from the Western Cape (Figure 2). Graf and Cummings (2011) provide one Western Cape locality at the coastal Little Brak River (Figure 3), while this study provides several other Western Cape localities (Figure 4). However, Graf and Cummings (2011) omit $U$. caffer records from five of the provinces including the Eastern Cape, Gauteng, Mpumalanga, Limpopo and North

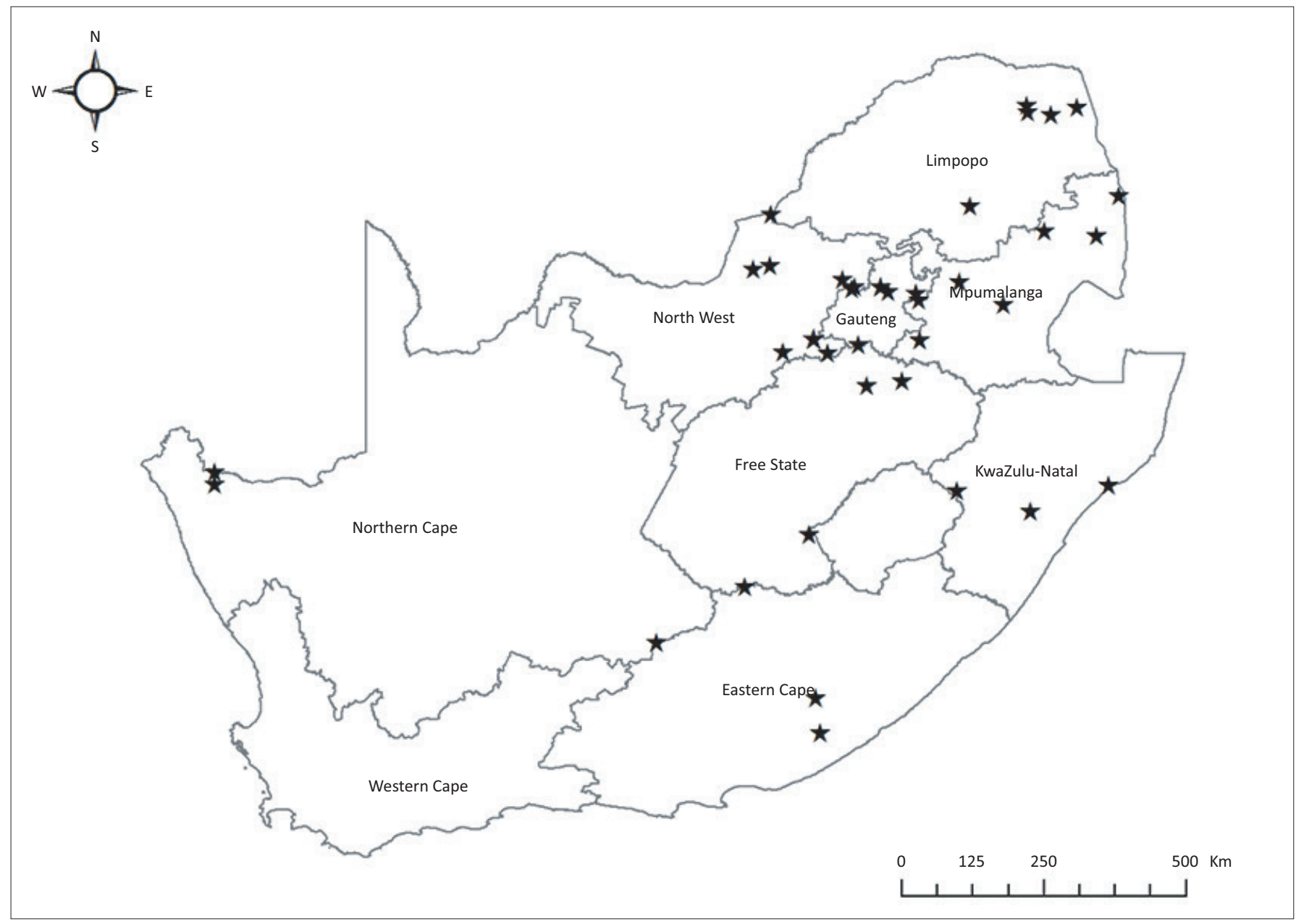

Source: De Kock, K.N. \& Wolmarans, C.T., 2010, 'Distribution and habitats of Unio caffer Krauss, 1848 (Bivalvia: Unionoida: Unionidae) in South Africa based on the records in the database of the National Freshwater Snail Collection', Suid-Afrikaanse Tydskrif vir Natuurwetenskap en Tegnologie 29, 173-186. https://doi.org/10.4102/satnt.v29i4.21

FIGURE 2: Distribution of Unio caffer in South Africa, redrawn using occurrence records from De Kock and Wolmarans (2010). The black stars represent U. caffer localities. 


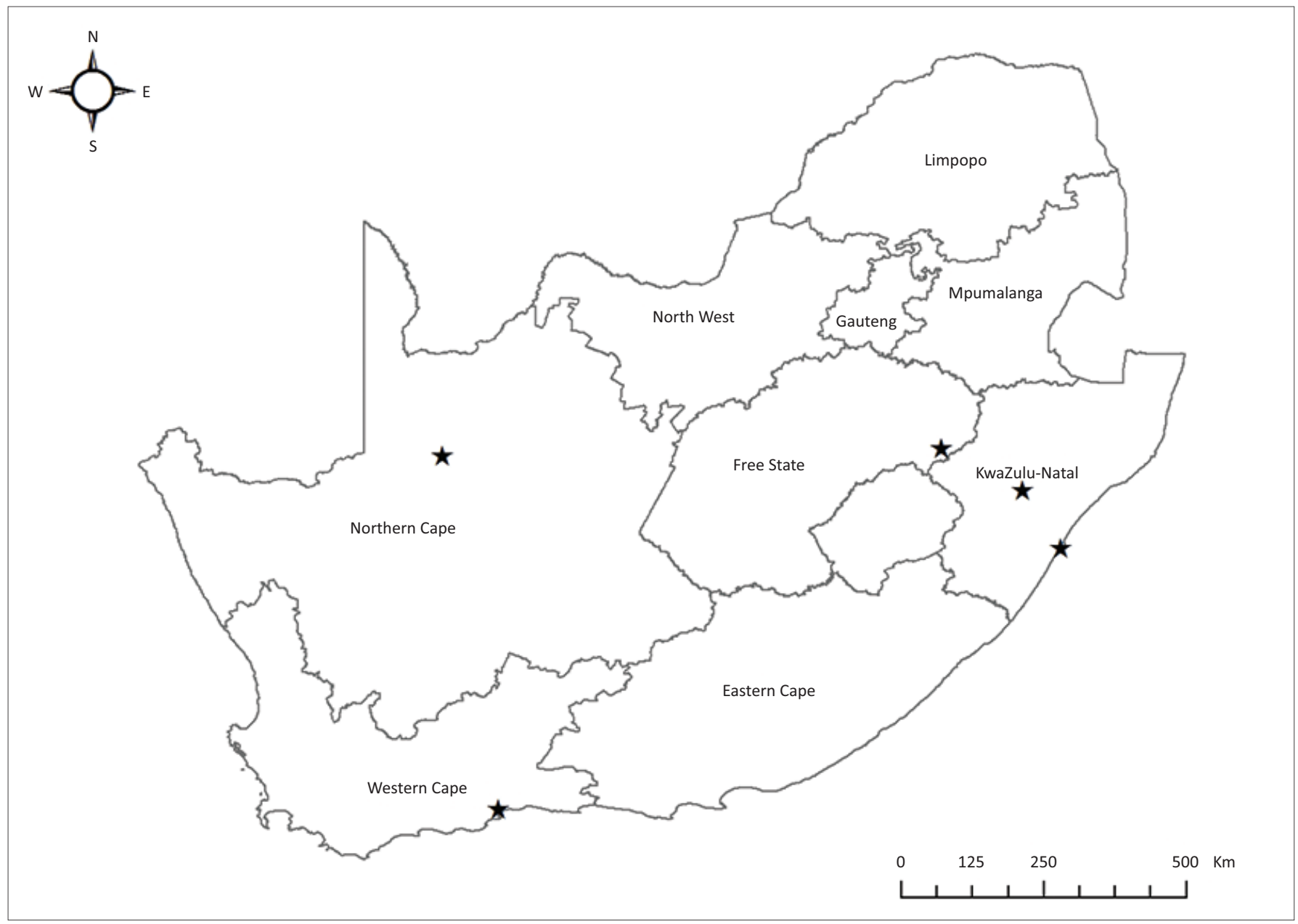

Source: Graf, D.L. \& Cummings, K.S., 2011, 'Freshwater mussel (Mollusca: Bivalvia: Unionoida) richness and endemism in the ecoregions of Africa and Madagascar based on comprehensive museum sampling', Hydrobiologia 678, 17-36. https://doi.org/10.1007/s10750-011-0810-5

FIGURE 3: Unio caffer distribution in South Africa redrawn using occurrence records from Graf and Cummings (2011). The black stars represent U. caffer localities.

West. Interestingly, museum records compiled in this study (Figure 4) show that there are more recorded $U$. caffer localities in the Eastern Cape than in any other province in South Africa. The concentration of data in the Eastern Cape, however, could possibly be because of the fact that some of the collectors, such as Carl Vernon from whom the majority of the specimens came from, were based in this province.

SAMC records show that $U$. caffer was collected in Retreat Vlei, Western Cape, in 1896, supporting Connolly (1939). This is the oldest record in all the collections. There are several other localities recorded in ELM and SAMC collections demonstrating the historical existence of this species in acidic waters of the Western Cape.

The integrated map (Figure 4) shows a much wider distribution of this species in South Africa than shown in the individual maps of De Kock and Wolmarans (2010) and Graf and Cummings (2011). It is concerning that there are very few recent records of this species from the 2000s onwards (Table 1).

\section{Discussion}

Museum collections are globally accepted as critical research assets, forming the basis for much of the biodiversity and biogeography research over the last two centuries (Pyke \& Ehrlich 2010; Suarez \& Tsutsui 2003). Nevertheless, a number of museum collections are in a neglected state, especially in developing countries (Cotterill \& Foissner 2010; Hamer 2012). Studies such as this are valuable to promote the use of museum collections to demonstrate biodiversity patterns of important species (Drinkrow, Cherry \& Siegfried 1994), which may in turn be used for policy development and management strategies. To this end, Graf and Cummings (2011) visited 17 museum collections across Europe, America and Australia, digitally photographing and capturing the metadata records for all the freshwater mussels. However, their lack of examination of African museums' collections in their study of African mussels was a misguided oversight. This study uses $U$. caffer to focus specifically within South Africa as a case study to demonstrate that omission of African museum collections will likely lead to an incomplete distribution map for African species.

Several authors have previously presented distributional occurrences of U. caffer at national (Appleton 2002; Brown 1978; Connolly 1939; Mandahl-Barth 1988) and regional (Brown 1967; De Kock \& Wolmarans 1998; Oberholzer \& Van Eeden 1967; Vernon 1999) levels within the country. As the more recent publications by De Kock and Wolmarans (2010) 


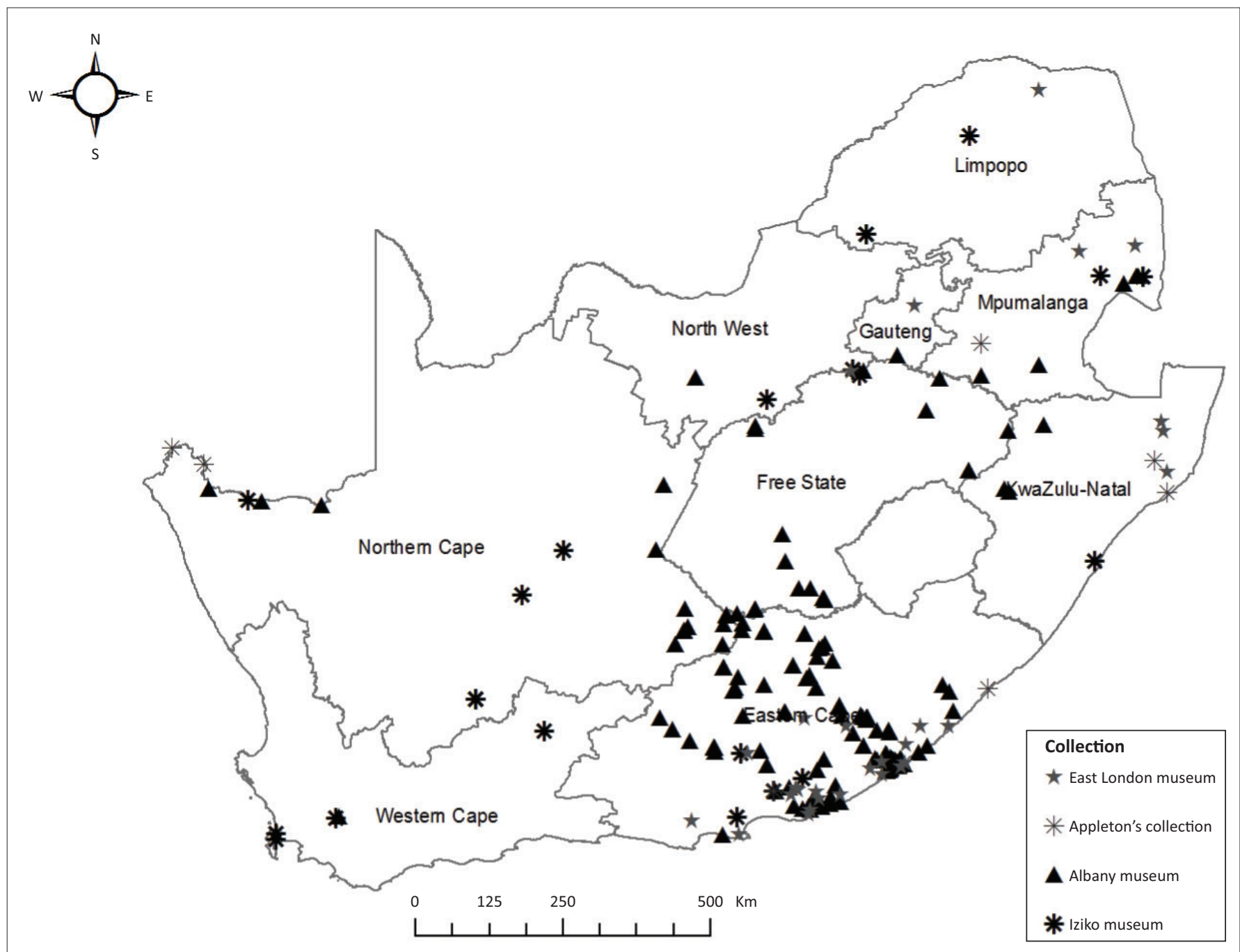

FIGURE 4: Distribution of Unio caffer in South Africa drawn using records from three South African museums (AMGS, ELM and SAMC) and personal collections by the third author (C.C.A.).

and Graf and Cummings (2011) on this species in South Africa present incomplete distributions, this article rectifies the issue by consulting local museums and by rigorously engaging published literature (Appleton 2002; Brown 1967, 1978; Connolly 1939; De Kock \& Wolmarans 1998; Mandahl-Barth 1988; Oberholzer \& Van Eeden 1967; Vernon 1999). The extensive museum records (Figures 4 and 5) revealed that the species had a wider historical distribution than reported by De Kock and Wolmarans (2010) and Graf and Cummings (2011).

Given that most of the records from the museum collections are in the form of empty shells (e.g. Figure 1), it is difficult to conclude whether they are part of the contemporary populations or historical ones that have already become extinct. The lack of recent material is a major concern (Table 1). Collecting live specimens of this species is not easy, as they bury themselves in the sediment and are well camouflaged (Figure 6). Live specimens are usually collected through snorkelling or diving down to the stream bottom. Traditionally, the easier way to collect live specimens is during drought periods when water recedes naturally, thus exposing the benthos to easy pickings (Appleton \& la Hausse de Lalouvière 1987 and Vernon C. pers. comm.). The discovery of new, live populations of this species
(Figure 5) in new locations is encouraging. Also, there have been long-term studies on population dynamics (recruitment and growth) of this species in the Eastern Cape (C. Vernon, formerly with ELM, pers. comm., 5 Nov 2015).

\section{Conclusion}

The current conservation status of Least Concern in the IUCN Red Data List for U. caffer (Kristensen, Stensgaard \& Appleton 2010) is deemed justifiable, even though its known distribution ranges have constricted in some parts (see Appleton 2002). Given that the larval stage of this species is obligatory parasitic on indigenous fishes (Vernon 1999), its persistence in the landscape is dependent on that of fishes' persistence. However, freshwater fishes are the most threatened large taxon in the world, with an estimated $25 \%$ of the evaluated freshwater fish species considered threatened with global extinction (Garrow \& Marr 2012). Understanding which species of indigenous fishes are the preferred host species for U. caffer (Vernon 1999) is a topic that still needs careful examination. Further, the negative impacts of invasive freshwater fishes on the native fish populations, when local ones are displaced or restricted only to upper headwaters 


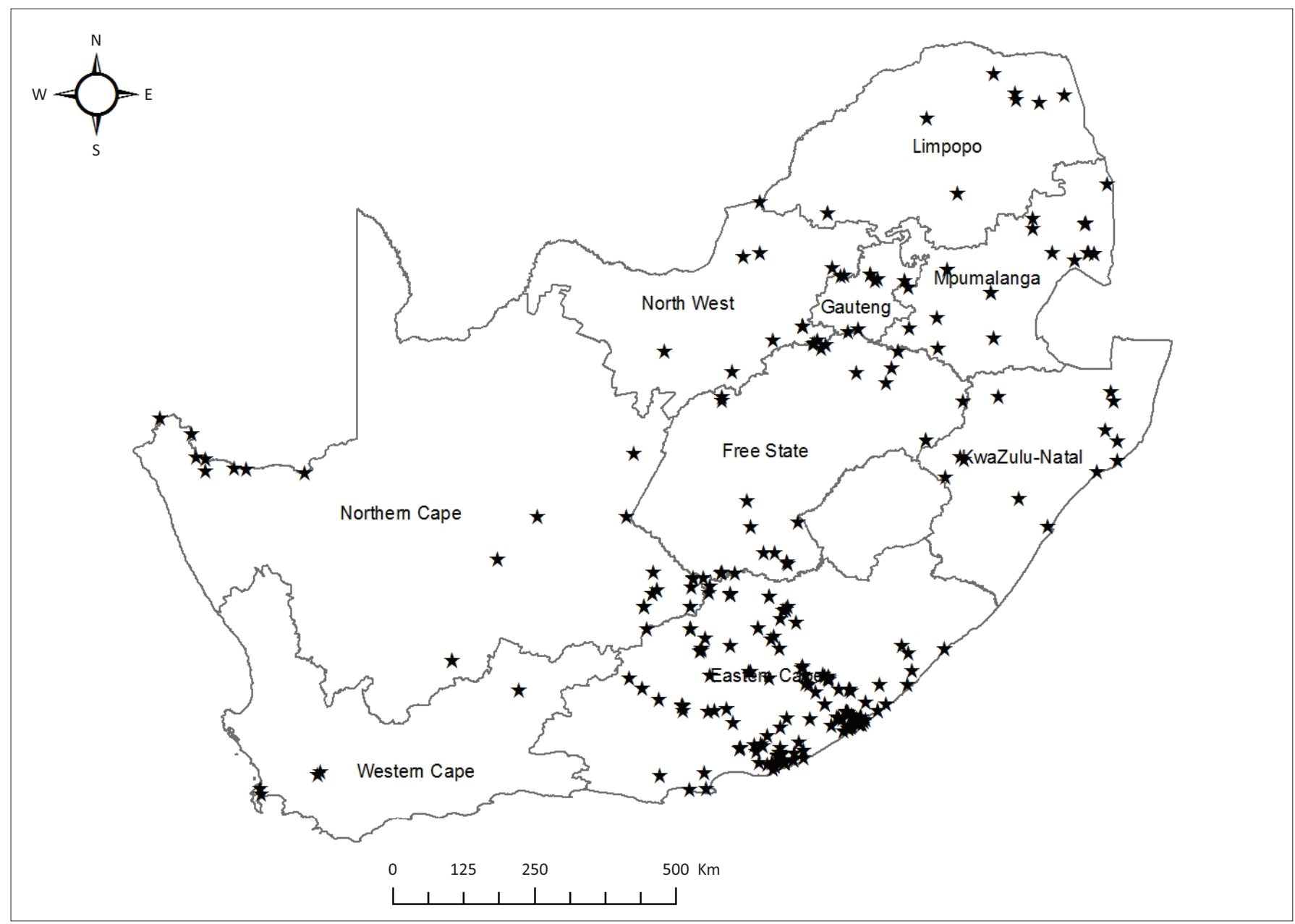

Source: Created by the current study based on the records from Figures 1-3

FIGURE 5: Integrated distribution map of Unio caffer in South Africa based on occurrence records from all the above sources (Figures 1-3). The black stars represent U. caffer localities.

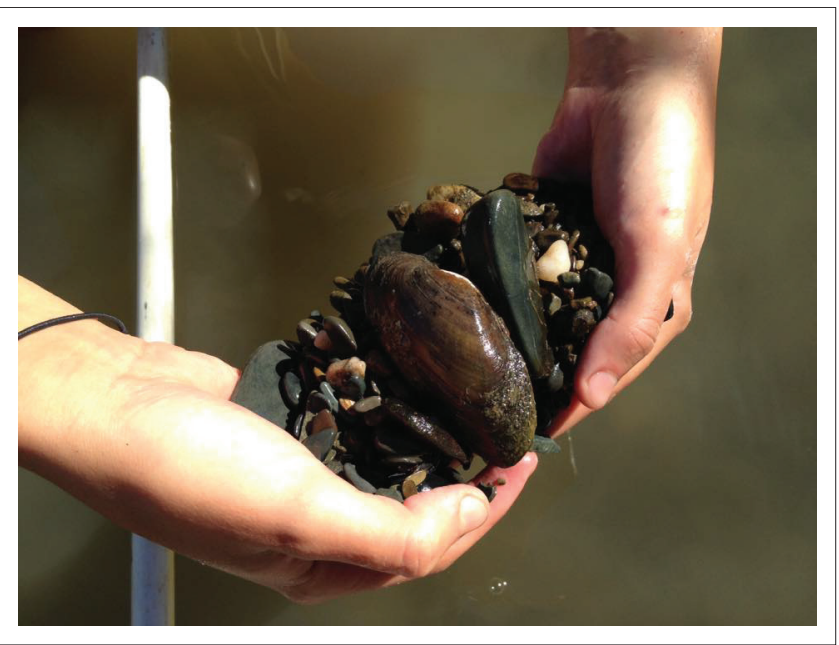

Source: Cecile Reed (C) (used with permission)

FIGURE 6: Live adult specimen of Unio caffer collected from sediments of the Oorlogskloof River, 19 April 2017, Oorlogskloof Nature Reserve in the Northern Cape, South Africa.

(Shelton, Samways \& Day 2015), will also likely further exacerbate the challenge of the long-term persistence of $U$. caffer. In the Western Cape, for example, where U. caffer has already been reported to havelost someground(Appleton 2002), and conservation status of their indigenous freshwater fishes is highly perilous (Garrow \& Marr 2012; Shelton et al. 2015), sustained, ongoing bio-monitoring of $U$. caffer is recommended. Disappearance of this species would reflect habitat degradation, which would indicate loss in overall biodiversity in the freshwater ecosystems in which it occurs.

\section{Acknowledgements}

Without Carl J. Vernon's immense collection of freshwater mussels from all over the country, which accounts for a large proportion of the specimens at Albany and East London Museum's collection, this study would not have been possible. So, the authors would like to pay special tribute to him. Curators of East London Museum (Mary Cole), Iziko Museum (Elizabeth Hoenson) and KwaZulu-Natal Museum (Igor Muratov) are greatly appreciated for providing Unio records from their museums. Sbongiseni Mazibuko from the Institute for Water Research (IWR), Rhodes University, assisted with producing the maps. Nompumelelo Baso and Tebadi Bopape assisted with laboratory work. The Knowledge Interchange and Collaboration (KIC) grant (UID 97304) from the National Research Foundation enabled the visit of the third author to Albany Museum, where the ideas of this article were discussed. 


\section{Competing interests}

The authors declare that that they have no financial or personal relationships that may have inappropriately influenced them in writing this article.

\section{Authors' contributions}

M.C.M. and C.C.A. conceptualised and performed the research. B.S., M.C.M., H.M.B.-J. and C.C.A. collected and analysed the data. All authors contributed to the write-up and discussion of the article.

\section{Funding}

This study was funded by the Knowledge Interchange and Collaboration (KIC) grant (UID 97304) from the National Research Foundation.

\section{References}

Appleton, C.C., 2002, 'Mollusca', in I.J. De Moor \& J.A. Day (eds.), Guides to the freshwater invertebrates of Southern Africa, Arachnida \& Mollusca, Araneae, Water Mites \& Mollusca, pp. 42-125, WRC Report No 182/02, Water Research Commission, Pretoria.

Appleton, C.C. \& La Hausse de Lalouvière, P. 1987, 'Some population characteristics of the bivalves of the Pongolo River floodplain', Journal of the Limnological Society of Southern Africa 13, 14-19. https://doi.org/10.1080/03779688.1987.9634538

Barber-James, H.M., 2010, 'Systematics, morphology, phylogeny and historical biogeography of the Mayfly family Prosopistomatidae (Ephemeroptera: Insecta) of the world', PhD thesis, Rhodes University.

Bauer, G. \& Wachtler, K., 2001, Ecology and evolution of the freshwater mussels Unionoida, Springer, Berlin.

Bilton, D.T., Toussaint, E.F.A., Turner, C.R. \& Balke, M., 2015, 'Capelatus prykei gen et sp.n. (Coleoptera: Dytiscidae: Copelatinae) - A phylogenetically isolated diving beetle from the Western Cape of South Africa', Systematic Entomology 40, 520-531. https://doi.org/10.1111/syen.12128

Bogan, A.E., 1993, 'Freshwater bivalve extinctions (Mollusca: Unionidae): A search for causes', American Zoologist 33, 599-609. https://doi.org/10.1093/icb/33.6.599

Bogan, A.E., 2008, 'Global diversity of freshwater mussels (Mollusca, Bivalvia) in freshwater', Hydrobiologia 595, 139-147. https://doi.org/10.1007/s10750-007 9011-7

Bologna, M.A., Audisio, P.A., Biondi, M. \& Casale, A., 2008, 'The biogeographical patterns of disjunct distribution with special emphasis on the Mediterranean and southern African model', Biogeographia 29, 7-17.

Brown, D.S., 1967, 'A review of the freshwater Mollusca of Natal and their distribution', Annals of Natal Musuem 18, 477-494.

Brown, D.S., 1978, 'Freshwater molluscs', in M.J.A. Werger (ed.), Biogeography and ecology of Southern Africa, pp. 1153-1180, Dr W. Junk b.v. Publishers, The Haque.

Connolly, M., 1939, 'A monographic study of South African non-marine Mollusca', Annals of the South African Museum 33, 1-660.

Cotterill, F.P.D. \& Foissner, W., 2010, 'A pervasive denigration of natural history misconstrues how biodiversity inventories and taxonomy underpin scientific knowledge', Biodiversity and Conservation 19, 291-303. https://doi.org/10.1007/ s10531-009-9721-4

De Kock, K.N. \& Wolmarans, C.T., 1998, 'A re-evaluation of the occurrence of freshwater molluscs in the Kruger National Park', Koedoe 41(1), 1-8. https://doi. org/10.4102/koedoe.v41i1.240

De Kock, K.N. \& Wolmarans, C.T., 2010, 'Distribution and habitats of Unio caffer Krauss, 1848 (Bivalvia: Unionoida: Unionidae) in South Africa based on the records in the database of the National Freshwater Snail Collection', SuidAfrikaanse Tydskrif vir Natuurwetenskap en Tegnologie 29, 173-186. https://doi. org/10.4102/satnt.v29i4.21

Drinkrow, D.R., Cherry, M.I. \& Siegfried, W.R., 1994, 'The role of natural history museums in preserving biodiversity', South African Journal of Science 90, $470-479$
Froufe, E., Gonçalves, D.V., Teixeira, A., Sousa, R., Varandas, S., Ghamizi, M. et al. 2016, 'Who lives where? Molecular and morphometric analyses clarify which Unio species (Unionida, Mollusca) inhabit the southwestern Palearctic region' Organisms and Diversity Evolution 16, 597-611. https://doi.org/10.1007/s13127Organisms

Garrow, C. \& Marr, S., 2012, Swimming on the edge of extinction: The perilous state of the indigenous freshwater fishes of the Western Cape, NISC (Pty) Ltd, Port Elizabeth.

Graf, D.L. \& Cummings, K.S., 2007, 'Review of the systematics and global diversity of freshwater mussel species (Bivalvia: Unionoida)', Journal of Molluscan Studies 73, 291-314. https://doi.org/10.1093/mollus/eym029

Graf, D.L. \& Cummings, K.S., 2011, 'Freshwater mussel (Mollusca: Bivalvia: Unionoida) richness and endemism in the ecoregions of Africa and Madagascar based on comprehensive museum sampling', Hydrobiologia 678, 17-36. https://doi. org/10.1007/s10750-011-0810-5

Hamer, M., 2012, 'An assessment of zoological research collections in South Africa', South African Journal of Science 108(11/12), Art. \#1090, 1-11.

Heard, W.H. \& Vail, V.A., 1976, 'The systematic position of Unio caffer (Pelecypoda: Unionoida: Unionidae)', Zoologica Africana 11, 45-58. https://doi.org/10.1080/ 00445096.1976.11447514

Jubb, R.A., 1976, 'Freshwater mussels, Unionidae, what is their distribution in South African inland waters today?', Piscator $97,73-75$

Khalloufi, N., Toledo, C., Machordom, A., Boumaïza, M. \& Araujo, R., 2011, 'The unionids of Tunisia: taxonomy and phylogenetic relationships, with redescription of Unio ravoisieri Deshayes, 1847 and U. durieui Deshayes, 1847', Journal of Molluscan Studies 77, 103-115. https://doi.org/10.1093/mollus/eyq046

Kristensen, T.K., Stensgaard, A.-S. \& Appleton, C., 2010, Unio caffer. The IUCN red list of threatened species 2010, viewed 25 May 2017, from https://doi.org/10.2305/ IUCN.UK.2010-3.RLTS.T63457A12680258.en

Lydeard, C., Cowie, R.H., Bogan, A.E., Bouchet, P., Cummings, K.S., Frest, T.J. et al., 2004, 'The global decline of nonmarine mollusks', BioScience 54, 321-330. https://doi.org/10.1641/0006-3568(2004)054[0321:TGDONM]2.0.CO;2

Mandahl-Barth, G., 1988, Studies on African freshwater bivalves, Danish Bilharziasis Laboratory, Charlottenlund.

Oberholzer, G. \& Van Eeden, J.A., 1967, 'The freshwater molluscs of the Kruger National Park', Koedoe 10, 1-42. https://doi.org/10.4102/koedoe.v10i1.762

Prié, V., Puillandre, N. \& Bouchet, P., 2012, 'Bad taxonomy can kill: Molecular reevaluation of Unio mancus Lamarck, 1819 (Bivalvia: Unionidae) and its accepted subspecies', Knowledge and Management of Aquatic Ecosystems 405, 18. https:// doi.org/10.1051/kmae/2012014

Pyke, G.H. \& Ehrlich, P.R., 2010, 'Biological collections and ecological/environmental research: A review, some observations and a look to the future', Biological Reviews 85(2), 247-266. https://doi.org/10.1111/j.1469-185X.2009.00098.x

Régnier, C., Fontane, B. \& Bouchet, P., 2009, 'Not knowing, not recording, not listing: numerous unnoticed mollusk extinctions', Conservation Biology 23, 1214-1221. https://doi.org/10.1111/j.1523-1739.2009.01245.x

Schwalb, A.N., Morris, T.J., Mandrak, N.E. \& Cottenie, K., 2012, 'Distribution of unionid freshwater mussels depends on the distribution of host fishes on a regional scale', Diversity and Distributions 19, 446-454. https://doi.org/10.1111/j.1472-4642. 2012.00940.x

Shelton, J.M., Samways, M.J. \& Day, J.A., 2015, 'Predatory impact of non-native rainbow trout on endemic fish populations in headwater streams in the Cape Floristic Region of South Africa', Biological Invasions 17, 365. https://doi.org/ 10.1007/s10530-014-0735-9

Strayer, D.L., 2008, Freshwater mussel ecology - A multifactor approach to distribution and abundance, University of California Press, Berkeley, CA.

Strayer, D.L., Downing, J.A., Haag, W.R., King, T.L., Layzer, J.B., Newton, T.J. et al., 2004 'Changing perspectives on pearly mussels, North America's most imperiled 'Changing perspectives on pearly mussels, North America's most imperiled
animals', BioScience 54, 429-439. https://doi.org/10.1641/0006-3568(2004) animals', BioScience 54, $429-1$
054[0429:CPOPMN]2.0.CO;2

Suarez, A.V. \& Tsutsui, N.D., 2003, 'The value of museum collections for research and society', BioScience 54(1), 66-74. https://doi.org/10.1641/0006-3568(2004)054 [0066:TVOMCF]2.0.CO;2

Vaughn, C. \& Hakenkamp, C., 2001, 'The functional role of burrowing bivalves in freshwater ecosystems', Freshwater Biology 46, 1431-1446. https://doi.org/ 10.1046/j.1365-2427.2001.00771 x

Vernon, C.J., 1999, 'Biogeography, endemism and diversity of animals in the Karoo', in W.R.J. Dean \& S.J. Milton (eds.), The Karoo, ecological patterns and processes, pp. 57-78, Cambridge University Press, Cambridge.

Watters, G.T., 1999, 'Freshwater mussels and water quality: A review of the effects of hydrologic and instream habitat alterations', in R.A. Tankersley, D.I. Warmolts, G.T. Watters, B.J. Armitage, P.D. Johnson \& R.S. Butler (eds.), Freshwater Mollusk Symposia Proceedings. Part II. Proceedings of the First Freshwater Mollusk Conservation Society Symposium, pp. 261-274, Ohio Biological Survey Special Publication, Columbus. 